\title{
New Economic Geography and the Conception of Social Factors of Criminality: Areas of Common Interest and Prospects for Synthesis
}

\author{
Dmitry V. Bakharev
}

\section{Surgut State Pedagogical University, Tumen Region, Surgut, 50 let VLKSM street, 10/2, 628400, Russia}

Abstract: The article discusses the application of «new economic geography» in investigating the reasons for territorial distinctions and other factors of criminality.

Keywords: Criminality factors, territorial distinctions of criminality, new economic geography.

\section{PRELIMINARY CONSIDERATIONS}

Investigating the reasons for territorial distinctions in criminality is the central issue in Russian criminology. Since the problem has been under discussion (the early XXth cent.), this issue has shaped the whole field of criminology. By investigating the territorial distinctions of criminality, researchers tried to find the reasons for criminality in general, that is, to find out its reasons as a social phenomenon. The researchers most successful in this field were criminologists of the Soviet period. While studying factors related to territorial distinctions in criminality, including the influence of demographics (Babaev et al. 1976), tendencies in different locations (Babaev et al. 1971; Zabryansky 1990), and the reasons for these differences (Gabiani and Gachechiladze 1982; The impact of social conditions... 1977; Crime territorial differences... 1988), Soviet scientists obtained good evidence that the genesis of criminality is primarily due to social and economic factors.

Under the administrative-command system and planned economy of the USSR, these scientific conclusions mattered to the organization of peoples' lives. The complete long-term control of nearly all areas of life in Soviet society made it possible to forecast criminologically significant social and economic factors that the government intended to address. For example, if Soviet criminologists were able to say that criminality increases in a region during its intensive exploration (because workers drawn to the region face difficulties unique to migrants as well as an insufficient social infrastructure, and so on), it may be possible to forecast the development of crime in that territory and

\footnotetext{
*Address correspondence to this author at the Surgut State Pedagogical University, Tumen Region, Surgut, 50 let VLKSM street, 10/2, 628400, Russia; Tel/Fax: (3462) 35-89-13; E-mail: demetr79@mail.ru
}

increase crime prevention there. Such possibilities explain the greater attention to and serious support for criminological investigations by the Soviet government from 1970-1980.

Whether there is the same opportunity in modern conditions is worth investigating. Under contemporary conditions, when social and economic processes develop in Russia accidentally and their regulation by the state and the regional governments is weak, studying the influence of these processes on criminality becomes problematic. However, even a cursory look at this problem shows that the findings of the Soviet period are not always consistent with the realities of today.

We first find that the most negative predictor of crime in all territories during the Soviet period was when the socio-economic sphere underwent significant positive transformations (expanding industrial activity, an influx of manpower, an increase in local incomes, etc.); however, the post-Soviet era demonstrated contradictory trends: the largest increase in crime was characterized by a higher degree of degradation of the socio-economic sphere. Unfortunately, not all trends were clear. In general, regions in Eastern Russia (the Urals and Siberia) displayed similar rates of crime increases to coincide with deteriorating socio-economic situations, whereas Central Russia (predominantly in the so-called Non-Black Earth Region) demonstrated a more gradual increase in crime rates.

Secondly, if you analyze the two "poles" of domestic crime, the smallest and largest crime levels, to determine an overall pattern in Russia, we should only consider regions other than the highest level of crime over the past decade. As a rule, eastern territories the Republics of Buryatia, Zabaykalsky Krai, and the Irkutsk and Kurgan Regions - with focused economies and significant rural populations, have a strong 
tendency to depopulate. Until recently, this group included regions highly contrasting in terms of their social and economic profiles, such as the industrially developed and highly urbanized territories of Ural namely, the Perm Krai and Sverdlovsk Regions. The regions gravitating to a "positive" pole of criminal tendencies are, strangely, the least economically and socially developed, such as the North Caucasus. Territories in Central and Southern Russia - Krasnodar Krai, and the Belgorod and Voronezh Regions - are dynamically developing in this regard. The Volga Region and the Republic of Mordovia are considerably lower than other regions in terms of rates, but have other good indicators of social and economic balance. Other regions are inexplicably stuck in a condition of stagnation, such as the Penza and Ryazan Regions.

Still, large "diversity" exists in all "median" groups, depending on the particular regional dynamics of crime. The median groups cannot be united into one group using any of the various criteria of social and economic development now known to criminologists. However, regions' considerable dynamic "mobility" between these "poles" of a crime rate can be observed (Bakharev 2011). There are regularities in terms of this "mobility," although in criminological science they have not been formalized.

Finally, if we turn to the role of demographic processes (in particular, urbanization and migration) in the formation of these differences, we find that not everything in the current situation can be explained by well-established theoretical views on the subject. Even a preliminary study of crime rates in the regions with the largest outflow and inflow of migrants (and consequently, low or high levels of urbanization) suggests that crime rates in these regions are significantly higher than those in the demographically "successful" regions (Bakharev 2013). This situation also differs significantly from recorded Soviet criminological science (Babaev et al. 1971).

What's the deal here? Is it a usage of erroneous social factors of crime or has the character and development of modern public relations in Russia, which has long established the views of Soviet scientists, changed? Are these scientists simply unable to adequately explain criminologically significant consequences?

Before attempting to answer these questions, it is necessary to understand that criminology depends to a great degree on the achievements of adjacent social and economic sciences (economics, sociology, social and economic geography, etc.), but they unfortunately haven't yet completely determined the development of social and economic processes in Russian society under contemporary conditions. Russian criminologists do not have a good idea about, for example, the mechanisms of migration, and they are not aware of the regularities of economic growth and provincial territories. Although all of the processes can be observed by the unaided eye, these processes do not present a complete picture according to the greater part of the representatives of the social sciences.

In this context, P. Krugman and his followers try to explain the regularities of irregular arrangements of economic factors across regions using mathematical tools in the theory of "new economic geography» (NEG), which was first articulated in the XXth century. The main postulates of NEG have the same views on the concentration of economic activity of people in space and its sequences, only in a more abstract way.

Thus, the work of J. Fridman («The policy of a region development: the experience of Venezuela», 1966) supported the idea that the theory of «centre and periphery» can play a serious part in explaining regularities in spatial development. The theory of "centre and periphery» demonstrates how centers of a different level (e.g., communities) tie up different resources from their periphery (e.g., human resources, natural resources, etc.) which makes it possible for these centers to develop at a greater speed. Further, these innovations are eventually transmitted to the periphery. This process was described previously as «innovation diffusions». The first to investigate this phenomenon was T. Hegerstrand («Innovation diffusions as a spatial process», 1953). He noted that innovation diffusions occur in two ways: first, according to the acquired system of communities (from the biggest to the smaller cities either in size or in administrative status), and second, to suburbs adjoining population centers.

Earlier, F. Perru (1950) theorized about «growth poles", that is, the location where production of leading fields begins to arrange and then becomes a center production and the locus of an economic pole. However, only P. Krugman and his supporters connected these ideas with current economic ideas (Fujita, Krugman. and Venables 2001). Only within the framework of NEG did the process of agglomeration formation, conditioned by its central and peripheral breaks in accordance with centrifugal and centripetal forces, become formalized (Pilyasov 2011:16). 
Our interest here is matching basic points of NEG with the data on criminal tendencies in some regions of the Russian Federation. Finding out definite, meaningful dependencies between direction and intensity of separate social processes provides grounds for a criminological theory of social factors in modern conditions. The character and peculiarities of these dependencies under market economics are explained in the context of NEG.

First, it is necessary to consider the statistical data characterizing the urban atmosphere of regions as well as the population as a whole. Russian supporters of NEG note that the theory of center-periphery relationships entail that if there are no huge economic centers on the territory, then the territory is expected to fall behind in social and economic development. For the steady development of a territory, the location of large cities must be equal and tense. In a resettlement system, population density is important: the higher the density of the population, the higher the size of the consumer market and the lower transport expenses on delivery of ready goods (Kuznetsova 2013:126). Other authors consider population density as a factor of spatial concentration of the production of goods and services and a factor of interregional differences of workforce productivity (Kolomak 2013:144).

\section{RESEARCH HYPOTHESIS}

We assume (with postulates of NEG) that the size and density of the population of a region (first, urban) and the average size of one community are data characterizing the general position of the social and economic spheres of the territory. The higher the size and density of the population of a town, the more economic, cultural and other creative activities a citizen has. A city becomes «the growth point», organizing a development of "central and peripheral» processes, and because of «innovation diffusions", it has a positive influence on the development of a nearby territory. Therefore, the dynamics in data of density of population of a region and average size of one of its communities show how advanced these regions are socially and economically from their inhabitants' point of view. The widely accepted idea in criminology that social factors are the genesis of criminality suggests that the more problematic territories are urban, which degrade more quickly in modern Russian society.

\section{RESEARCH METHODOLOGY}

Under review were 11 of the 13 regions in Central Russia (Leyzerovich 2010). Moscow and the Moscow region were excluded for their extreme differences on all characteristics from the rest of the group, some of which contain regions similar to Moscow in their social and economic conditions. All of the regions are under the great negative influence of Moscow agglomeration in «drawing out» human resources. Static and dynamic data characterizing the state and tendencies of population changes in each region are presented in Tables 1-4.

The state and dynamics of criminality were investigated by region from 2003-2011 (the data for 2012 have not been officially published by the Federal Service of State Statistics of the RF). The year of the

Table 1: Square and Number of Population

\begin{tabular}{|c|c|c|c|c|c|c|}
\hline & & $\begin{array}{c}\text { Square, thous. } \\
\mathbf{k m}^{2}\end{array}$ & $\begin{array}{l}\text { Population, } \\
\text { people (2002) }\end{array}$ & $\begin{array}{l}\text { Population, } \\
\text { people (2010) }\end{array}$ & $\begin{array}{c}\text { Urban } \\
\text { population, } \\
\text { people (2010) }\end{array}$ & $\begin{array}{c}\text { Urban } \\
\text { population, } \\
\text { people (2002) }\end{array}$ \\
\hline 1 & The Bryansk Region & 34,9 & 1378941 & 1278217 & 883427 & 943382 \\
\hline 2 & The Vladimir Region & 29,1 & 1523990 & 1443693 & 1120671 & 1213865 \\
\hline 3 & The Ivanovo Region & 21,4 & 1148329 & 1061651 & 859335 & 949249 \\
\hline 5 & The Kostroma Region & 60,2 & 736641 & 667562 & 466689 & 496145 \\
\hline 6 & The Oryol Region & 24,7 & 860262 & 786935 & 515404 & 546478 \\
\hline 7 & The Ryazan Region & 39,6 & 1227910 & 1154114 & 818349 & 846180 \\
\hline 8 & The Smolensk Region & 49,8 & 1049574 & 985537 & 716299 & 743599 \\
\hline
\end{tabular}


Table 2: The Number of Urban Communities and Communities without People

\begin{tabular}{|c|c|c|c|c|}
\hline & & The number of towns & $\begin{array}{c}\text { The number of urban-type } \\
\text { settlements }\end{array}$ & $\begin{array}{c}\text { The number of } \\
\text { communities without } \\
\text { people (2010) }\end{array}$ \\
\hline \hline 1 & The Bryansk Region & 16 & 24 & 316 \\
\hline 2 & The Vladimir Region & 23 & 9 & 316 \\
\hline 3 & The Ivanovo Region & 17 & 13 & 451 \\
\hline 4 & The Kaluga Region & 22 & 10 & 1189 \\
\hline 5 & The Kostroma Region & 12 & 7 & 344 \\
\hline 6 & The Oryol Region & 7 & 22 & 361 \\
\hline 7 & The Ryazan Region & 12 & 12 & 978 \\
\hline 8 & The Smolensk Region & 15 & 28 & 2230 \\
\hline 9 & The Tver Region & 23 & 25 & 487 \\
\hline 10 & The Tula Region & 19 & 13 & 1550 \\
\hline 11 & The Yaroslav Region & 11 & & \\
\hline
\end{tabular}

Table 3: Dynamics of Density of Population (2002-2010)

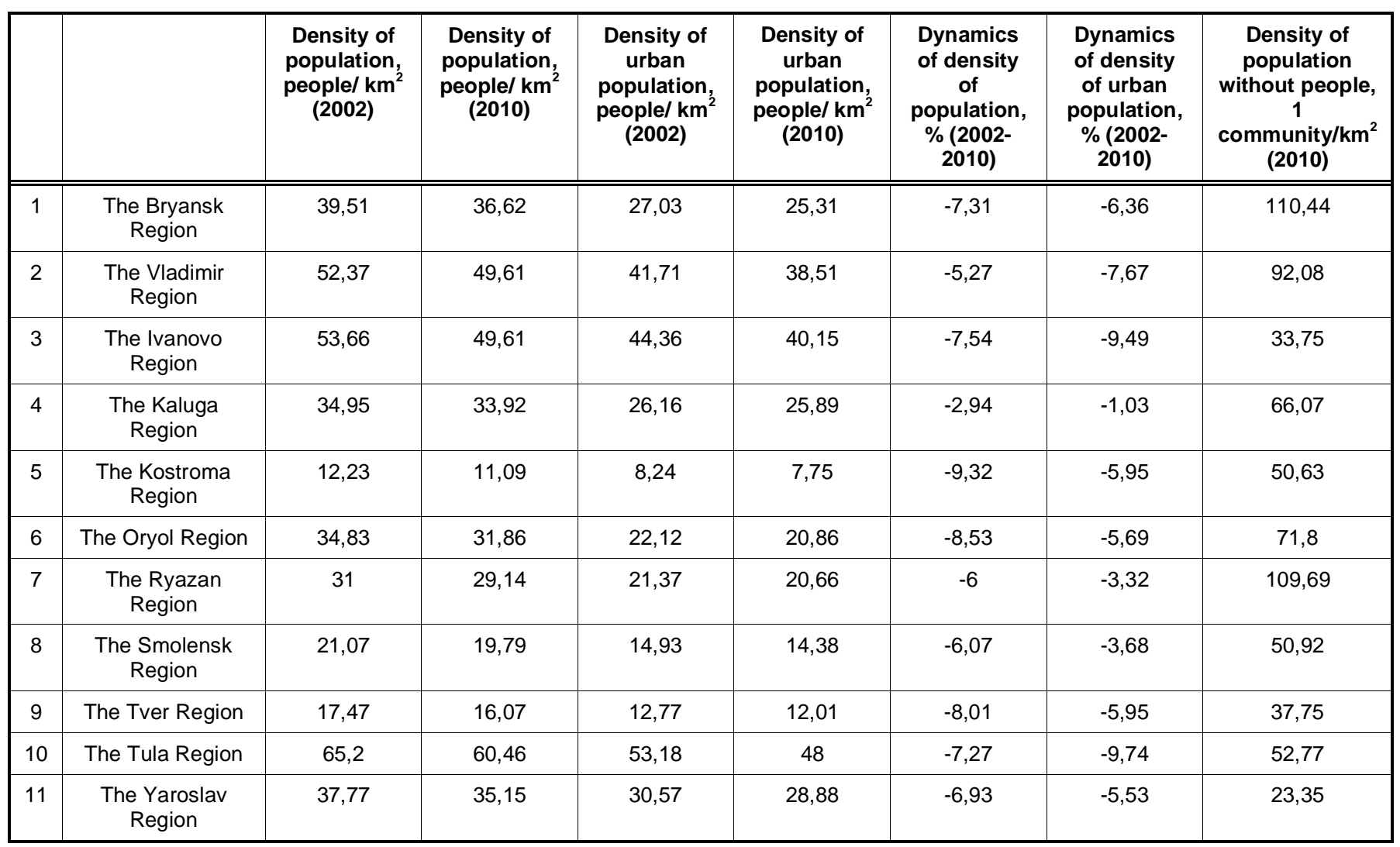

population census (2002) was purposefully excluded from the period because of an evident fall in crime. However, as mentioned in the criminological literature, the fall in crime was caused not by success in crime prevention but by the release of a new criminal procedure code (which came into force July 1, 2002) that greatly complicated the work of law-enforcement and had a negative impact on crime registration (Luneev 2005:210, 2007:52). The average level of crime (the number of fixed crimes per 100,000 people) from 2003-2011 was chosen as the index of criminality (Table 5). The dynamics of criminality is characterized 
Table 4: The Number and Dynamics of the Average Number of One Community (2002-2010)

\begin{tabular}{|c|c|c|c|c|}
\hline & & $\begin{array}{l}\text { The average number of } \\
\text { population of one urban } \\
\text { community, people (2002) }\end{array}$ & $\begin{array}{l}\text { The average number of } \\
\text { population of one urban } \\
\text { community, people (2010) }\end{array}$ & $\begin{array}{l}\text { Dynamics of the average } \\
\text { number of population of one } \\
\text { urban community, \% (2002- } \\
2010)\end{array}$ \\
\hline 1 & The Bryansk Region & 23584 & 22085 & $-6,35$ \\
\hline 2 & The Vladimir Region & 37933 & 35020 & $-7,68$ \\
\hline 3 & The Ivanovo Region & 31641 & 28644 & $-9,47$ \\
\hline 4 & The Kaluga Region & 24358 & 24114 & -1 \\
\hline 5 & The Kostroma Region & 26112 & 24562 & $-5,93$ \\
\hline 6 & The Oryol Region & 27323 & 25770 & $-5,68$ \\
\hline 7 & The Ryazan Region & 24887 & 24069 & $-3,28$ \\
\hline 8 & The Smolensk Region & 27540 & 26529 & $-3,67$ \\
\hline 9 & The Tver Region & 21093 & 19831 & -6 \\
\hline 10 & The Tula Region & 31064 & 28038 & $-9,74$ \\
\hline 11 & The Yaroslav Region & 46116 & 43563 & $-5,53$ \\
\hline
\end{tabular}

Table 5: Criminality Level (2003-2011)

\begin{tabular}{|c|c|c|c|c|c|c|c|c|c|c|c|}
\hline & & 2003 & 2004 & 2005 & 2006 & 2007 & 2008 & 2009 & 2010 & 2011 & $\begin{array}{c}\text { The } \\
\text { average } \\
\text { level 2003- } \\
2011\end{array}$ \\
\hline 1 & The Bryansk Region & 1809 & 1856 & 2321 & 2191 & 2148 & 2049 & 1982 & 1833 & 1533 & 1969,111 \\
\hline 2 & The Vladimir Region & 1913 & 2140 & 2471 & 2497 & 2296 & 1956 & 1898 & 1775 & 1659 & 2067,222 \\
\hline 3 & The Ivanovo Region & 2266 & 2170 & 2377 & 2462 & 2302 & 1939 & 1827 & 1771 & 1628 & 2082,444 \\
\hline 4 & The Kaluga Region & 1766 & 2026 & 2541 & 2541 & 2263 & 2095 & 1938 & 1776 & 1496 & 2049,111 \\
\hline 5 & The Kostroma Region & 2197 & 2214 & 2466 & 2345 & 2007 & 1640 & 1587 & 1480 & 1394 & 1925,556 \\
\hline 6 & The Oryol Region & 1901 & 1941 & 2282 & 2512 & 2478 & 2106 & 1897 & 1730 & 1610 & 2050,778 \\
\hline 7 & The Ryazan Region & 1023 & 963 & 1450 & 1373 & 1175 & 1155 & 951 & 916 & 845 & 1094,556 \\
\hline 8 & The Smolensk Region & 2070 & 2312 & 2779 & 2738 & 2423 & 2297 & 2291 & 2116 & 1856 & 2320,222 \\
\hline 9 & The Tver Region & 1967 & 2037 & 2850 & 2964 & 2795 & 2585 & 2473 & 2202 & 2150 & 2447 \\
\hline 10 & The Tula Region & 1116 & 1170 & 1261 & 1306 & 1229 & 1150 & 1145 & 1023 & 949 & 1149,889 \\
\hline 11 & The Yaroslav Region & 2380 & 2754 & 3420 & 3097 & 2681 & 2288 & 2077 & 1673 & 1454 & 2424,889 \\
\hline
\end{tabular}

by two indexes: 1) the criminality level growth (from 2003-2006); and 2) the criminal level fall (from 20062011) in percent. (See Table 6. The data are given according to: Regions of Russia... 2012.)

With the help of defining the paired linear correlation size, there is a correlation between the criminality index and population density.

\section{RESULTS}

The analysis showed that there is a correlation between the criminality index and all indexes of population density and region size (Table 7 ). Thus, the latter index correlates positively with the criminality: the larger the region is, the higher the level of criminality is (the correlation coefficient $-0,34$ ). There is a negative correlation between the average crime level and static indexes of population density, including urban areas (the correlation coefficient - from $-0,14$ to $-0,49$ ). The higher these indexes, the more likely the crime level will be less than average.

According to the results of correlation analysis (Table 8), the indexes of criminality interact differently 
Table 6: Dynamics of Increase and Fall of Criminality Level (2003-2011)

\begin{tabular}{|c|c|c|c|c|c|c|c|c|c|c|c|}
\hline & & 2004 & 2005 & 2006 & 2007 & 2008 & 2009 & 2010 & 2011 & $\begin{array}{c}\text { The } \\
\text { general } \\
\text { increase }\end{array}$ & $\begin{array}{c}\text { The } \\
\text { general } \\
\text { fall }\end{array}$ \\
\hline 1 & The Bryansk Region & $+2,53$ & $+25,05$ & $-5,6$ & $-1,96$ & $-4,61$ & $-3,27$ & $-7,52$ & $-16,36$ & $+28,3$ & $-33,95$ \\
\hline 2 & The Vladimir Region & $+11,86$ & $+15,47$ & $+1,05$ & $-8,05$ & $-14,8$ & $-2,96$ & $-6,48$ & $-6,53$ & $+30,53$ & $-33,56$ \\
\hline 3 & The Ivanovo Region & $-4,24$ & $+9,54$ & $+3,58$ & $-6,5$ & $-15,77$ & $-5,77$ & $-3,06$ & $-8,07$ & $+8,65$ & $-33,87$ \\
\hline 4 & The Kaluga Region & $+14,72$ & $+25,42$ & 0 & $-10,94$ & $-7,42$ & $-7,49$ & $-8,36$ & $-15,76$ & $+43,88$ & $-41,12$ \\
\hline 5 & $\begin{array}{c}\text { The Kostroma } \\
\text { Region }\end{array}$ & $+0,77$ & $+11,38$ & $-4,91$ & $-14,41$ & $-18,29$ & $-3,23$ & $-6,74$ & $-5,81$ & $+12,24$ & $-43,47$ \\
\hline 6 & The Oryol Region & $+2,1$ & $+17,57$ & $+10,08$ & $-1,35$ & $-15,01$ & $-9,92$ & $-8,8$ & $-6,93$ & $+32,14$ & $-35,91$ \\
\hline 7 & The Ryazan Region & $-5,86$ & $+50,57$ & $-5,31$ & $-14,42$ & $-1,7$ & $-17,66$ & $-3,68$ & $-7,75$ & $+41,74$ & $-41,72$ \\
\hline 8 & $\begin{array}{c}\text { The Smolensk } \\
\text { Region }\end{array}$ & $+11,69$ & $+20,2$ & $-1,48$ & $-11,5$ & $-5,2$ & $-0,26$ & $-7,64$ & $-12,29$ & $+34,25$ & $-33,21$ \\
\hline 9 & The Tver Region & $+3,56$ & $+39,91$ & +4 & $-5,7$ & $-7,51$ & $-4,33$ & $-10,96$ & $-2,36$ & $+50,68$ & $-27,46$ \\
\hline 10 & The Tula Region & $+4,84$ & $+7,77$ & $+3,57$ & $-5,89$ & $-6,43$ & $-0,43$ & $-10,65$ & $-7,23$ & $+17,02$ & $-27,33$ \\
\hline 11 & The Yaroslav Region & $+15,71$ & $+24,18$ & $-9,44$ & $-13,43$ & $-14,66$ & $-9,22$ & $-19,45$ & $-13,09$ & $+43,7$ & $-53,05$ \\
\hline
\end{tabular}

Table 7: The Degree of Correlation of the Size of the Average Criminality Level with the Indexes of Number, Density of Population and the Square of Regions

\begin{tabular}{|c|c|c|c|c|c|c|}
\hline & $\begin{array}{c}\text { Square, } \\
\text { thous. } \mathbf{k m}^{2}\end{array}$ & $\begin{array}{c}\text { Population, } \\
\text { people }\end{array}$ & $\begin{array}{c}\text { Urban } \\
\text { population, } \\
\text { people. (2010) }\end{array}$ & $\begin{array}{c}\text { Density of } \\
\text { population, } \\
\text { people./km² } \\
\mathbf{( 2 0 1 0 )}\end{array}$ & $\begin{array}{c}\text { Density of urban } \\
\text { population, } \\
\text { people./km } \\
\text { (2010) }\end{array}$ & $\begin{array}{c}\text { Density of } \\
\text { population of } \\
\text { communities } \\
\text { without people, } \\
\mathbf{1} \\
\text { community/km } \\
\text { (2010) }\end{array}$ \\
\hline \hline $\begin{array}{c}\text { The average criminality } \\
\text { level }\end{array}$ & 0,34 & $-0,19$ & $-0,14$ & $-0,39$ & $-0,35$ & $-0,49$ \\
\hline
\end{tabular}

Table 8: The Degree of Correlation of Indexes of Dynamics of Criminality Level with the Indexes of Dynamics and Density of Population and Changes in Average Number of One Community

\begin{tabular}{|c|c|c|c|}
\hline & $\begin{array}{c}\text { Dynamics of density } \\
\text { of population, \% } \\
\mathbf{( 2 0 0 2 - 2 0 1 0 )}\end{array}$ & $\begin{array}{c}\text { Dynamics of density } \\
\text { of urban population, \% } \\
\mathbf{( 2 0 0 2 - 2 0 1 0 )}\end{array}$ & $\begin{array}{c}\text { Dynamics of average } \\
\text { number of one urban } \\
\text { community, \% (2002- } \\
\mathbf{2 0 1 0 )}\end{array}$ \\
\hline \hline General increase level of criminality, \% & 0,44 & 0,67 & $-0,66$ \\
\hline General fall level of criminality, \% & $-0,11$ & $-0,44$ & $-0,44$ \\
\hline
\end{tabular}

with population density and the change in number of one urban community. Thus, the increase of the crime level showed the direct dependence on the given indexes (correlation coefficient - from 0, 44 to 0,67 ): a smaller population density corresponds to a lower crime level. Conversely, the tendency of the crime level to fall correlates negatively with the indexes of population density: as migration rates from regions decrease, crime rates fall more quickly (correlation coefficient - from $-0,11$ to $-0,44$ ).
Therefore, if population development in a particular region occurs positively (it is a natural phenomenon and better in terms of socio-economic development than other regions belonging to the same typological group), criminality tendencies in this region will be more favorable. This conclusion is another argument in favor of the social conditioning of criminality.

\section{CONCLUSIONS}

The results are a serious argument in favor of the synthesis of basic conclusions of «new economic 
geography» with the accumulated experience of criminologists in investigating the reasons for territorial distinctions in criminality. The current research was conducted with simple methods using a small amount of official statistics grouped if not at random, according to region; these methods provided valid results. If a Russian typology of regions was created using different criteria with other static regional data, the results may be more impressive.

Thus, as the research shows, if the population of the region develops according to a more optimistic scenario, the probability is great that crime tendencies will be more favorable in comparison to other territories where the demographic situation is less positive. Follow-up studies may find a relationship between migratory activity and the number of crimes. Moreover, if a positive correlation is detected between population growth that increases the overall level of socioeconomic situation of the region (which directly fits into the framework of NEG), it will be a serious argument in favor of the concept of social conditioning of crime, and evidence that the influence of social factors on crime in a market economy works fundamentally differently than in the planned method of state and Social Construction.

These results serve as a serious argument in favor of the synthesis of "new economic geography" and the experience of criminologists researching the reasons for and regularities of territorial distinctions of crime. Perhaps the application of «new economic geography» in criminological research will confirm long-standing ideas about conditioning changes in criminality through different social processes.

\section{REFERENCES}

Babaev M., Karpets I., Kuznetsova E., Nikiforov A. et al . 1971. «The study of crime in urban and rural». Moscow: Legal literature.
Babaev M., Kuznetsova E., Urlanis E. 1976. "The impact of demographic processes on crime». Moscow: Legal literature.

Bakharev Dmitry V. 2011. "Design and Analysis of criminological classification of regions of the Russian Federation in 2001 to 2009 with using the cluster approach». Improvement of law enforcement to fight crime in modern conditions. Tyumen: TGAMEUP: 63-67.

Bakharev Dmitry V. 2013. "The nature of modern demographic processes in Russia and their account in studying the causes of crime». Problems of codification of the criminal law: Past, Present, Future. Moscow: Yurlitinform: 400-404.

Crime territorial differences and their causes. Collection of scientific papers. 1988. Moscow: Publishing VNIISZ.

Fujita M., Krugman P., and Venables A.J. 2001. "The spatial economy. Sities, Regions, and International Trade». Cambridge, MA: MIT Press.

Gabiani, Gachechiladze. 1982. "Some questions of geography of crime. According to the materials of the Georgian SSR». Tbilisi: Tbilisi University Publisher.

Kuznetsova, Olga. A. 2013. "Pyramid of Factors of Regional SocioEconomic Development». Question of Economics 2:121-131.

Kolomak Eugene A. «Uneven Spatial Development n Russia: Explanations of New Economic Geography». Questions of Economics 2:132-149.

Leyzerovich, Eugene E. 2010. «The net of economic micro zones in Russia, the version of 2008». Regional Studies 4:14-28.

Luneev, Victor V. 2005. "Crime of the twentieth century: global, regional and Russian tendencies». Moscow: Wolters Kluwer.

Luneev, Victor V. 2007. «Problems of jurisprudence criminal cycle». State and Law 5:39-58.

National Census. 2002. http://perepis2002.ru/index.html?id=13

National Census. 2010. http://www.gks.ru/free doc/new site/ perepis2010/croc/perepis_itogi1612.htm

Pilyasov, Alexander. N. 2011. "New Economic Geography: Preconditions, Ideological Basis and Applicability of the Models». Bulletin of the Russian Academy of Sciences. Series of geographical 7:7-17.

Regions of Russia. Socio-economic indicators. 2012. Moscow: Rosstat.

The impact of social conditions on the spatial differences in crime. 1977. Moscow: Publishing VNIISZ.

Zabryansky Grigory I.1990. "Criminological problems of the village. Methodology and research». Rostov-on-Don: Rostov Publisher University.

Received on 30-12-2013

Accepted on 21-02-2014

Published on 10-03-2014

\section{DOI: http://dx.doi.org/10.6000/1929-4409.2014.03.07}

(C) 2014 Dmitry V. Bakharev; Licensee Lifescience Global.

This is an open access article licensed under the terms of the Creative Commons Attribution Non-Commercial License (http://creativecommons.org/licenses/by-nc/3.0/) which permits unrestricted, non-commercial use, distribution and reproduction in any medium, provided the work is properly cited. 